\title{
The Application of the Problem Based Learning Training Model in Prioritizing the Learning Needs of the Community in Kampung KB
}

\author{
Joni R Pramudia*, Achmad Hufad, Mupid Hidayat, Purnomo, Hodijah Wulandari \\ Community Education Department \\ Universitas Pendidikan Indonesia \\ Bandung, Indonesia \\ *jonirp@upi.edu,achmadhufad@upi.edu, hidayatmupid@upi.edu,purnomo@upi.edu,hodijahw@student.upi.edu
}

\begin{abstract}
Researchers examine the needs assessment process as the most important component in mapping problems in the community, determining priority needs so as to produce programs that are relevant to community needs. One of the implementations of community empowerment programs in addressing current population problems is the $K B$ village program implemented by the National Population and Family Planning Board (Badan Kependudukan dan Keluarga Berencana Nasional, BKKBN). However, problems with the realization of the KB village program were found due to the lack of synchronization between community needs and program implementation, resulting in some programs not being fully felt by the community. In addition, the competence of $\mathrm{KB}$ village cadres in implementing the Needs Assessment needs to be improved so that they are able to carry out more effective and efficient performance through training programs by applying a training model with a problem-based learning (PBL) approach. This study used a qualitative approach, with data collection procedures, observation guidelines, interview guidelines and documentation studies. The results showed that the formation and development of training participants' knowledge occurred through social interaction. Learning for training participants in the PBL model is an effort to achieve knowledge to prioritize the learning needs of the KB village community in Citeureup Village, Bandung Regency.
\end{abstract}

Keywords—need assessment, problem based learning, training

\section{INTRODUCTION}

Green Paper [1] in the White Paper Learning for Life [2] formulates that the contribution of community empowerment programs in education is very recognized and important, namely:

- Reaching out to the wider community, often attracting disadvantaged people.

- Pioneering new approaches to learning based on community needs.
- Community life experiences (participants) as a starting point for making decisions

The essence of community empowerment programs is carried out based on a grassroots approach, namely starting from exploring the problems faced by the community, so that gaps or gaps in the needs of the community are found. In the process, the community as an actor who reflects the individual needs and local needs of the developing community. The process of building community capacity is carried out in the form of involvement in decision making and policy formation in the community [3-5].

Program planning designed in community empowerment is around community needs, starting with getting to know each other between the facilitator and the community, then moving on to the content of more specific needs. The process of identifying needs requires accuracy in collecting and processing data [6-8].

The process of identifying needs to apply the right method so that all information can be obtained completely. Minzey and Le Tarte [9] emphasize that "community empowerment is a process, where community members work together to identify problems and to find solutions to these problems".

The researcher examines the needs assessment process as the most important component in mapping problems in the community, determining priority needs so as to produce programs that are relevant to community needs. Programs that can be felt directly by the community are real programs obtained from the priority needs themselves [6].

One of the implementations of the community empowerment program in addressing current population problems is the $\mathrm{KB}$ village program implemented by the National Population and Family Planning Board (BKKBN). However, problems with the realization of the $\mathrm{KB}$ village program were found due to the lack of synchronization between community needs and program implementation, 
resulting in some programs not being fully felt by the community.

In addition, based on a preliminary study, the competence of $\mathrm{KB}$ village cadres in carrying out the Needs Assessment needs to be improved so that they are able to carry out more effective and efficient performance. Some of the problems related to these competencies include: 1) the majority of cadres are over 35 years of age with varied educational backgrounds and educational experiences, so that their level of knowledge about assessment is limited, 2) training related to needs assessment techniques in community empowerment programs is still limited, 3) the availability of data houses that accommodate sources of information or data is still minimal, because the process of obtaining data and processing data takes a relatively long time, this condition is accompanied by the ability of untrained cadres.

In connection with these conditions, this research was conducted to improve the competence of $\mathrm{KB}$ village cadres in prioritizing the learning needs of the $\mathrm{KB}$ village community, so that later the community would receive programs that match their needs through training programs.

In setting priorities for the learning needs of the community in the $\mathrm{KB}$ village, the learning model of "learning by doing" is thick as a learning experience that is able to attract the attention of training participants by uncovering community "problems" "Learning by doing to explore problems, learning of needs" in training was carried out using the WatchingLearning-Doing strategy. Meanwhile, the training material must address the needs and problems of the training participants themselves as the competence of KB Village cadres that is achieved by each individual.

In the implementation of training, priority is the "experience" of the training participants, so the most important thing in the training is the content and meaning of prioritizing the learning needs of the community, not just the implementation of the program. From this description, a training model that integrates problems and is project-based is needed, namely the training model with the PBL (Problem Based Learning) approach.

The training model with the PBL (Problem Based Learning) approach as disclosed [10] is to help trainees develop thinking skills, problem solving and intellectual skills, learn to share adult roles by involving them in real or simulated experiences. Problem-based learning will also make the trainees become autonomous, independent learners.

In addition, problem-based learning will help develop (1) thinking skills and problem-solving skills. (2) The collaboration carried out in problem-based learning will encourage the emergence of various inquiry and dialogue skills thereby developing social and thinking skills, (3) through a problem-based learning participants will pitch thrust become autonomous learners and independent in solving problems encountered in life [10]. Based on the analysis, this research will examine the application of problem based learning model and develop the learning needs of the community.

\section{METHODS}

This study uses a qualitative approach with data collection techniques of orientation, exploration, and member check stages. And the data collection tools used were observation guidelines, interview guides and documentation studies [11]. The focus of this research is the implementation of a training model by applying a problem-based learning model to prioritize the learning needs of the community in the $\mathrm{KB}$ Village, Citeureup Village, Bandung Regency, with 15 cadres of KB village cadres. Key informant consists of 3 trainees and 1 training program organizer.

Informants in this study are the participants of the training program. Triangulation is done to test the credibility of data by checking the data that has been obtained through various sources.

\section{FINDINGS AND DISCUSSION}

The application of the training model with the problembased learning (PBL) approach generally begins with a problem that must be solved by the training participants. These problems can come from the trainees or from the instructors. The training participants will focus their learning around the problem, in other words, the trainees learn scientific theory and method in order to solve the problem that is the center of their attention. Problem solving in problem-based learning must be in accordance with the steps of the scientific method. Thus the training participants learn to solve problems in a systematic and planned manner.

Problem-based learning was initiated as a form of tactical and proactive steps through a process of assessment and analysis based on the empirical conditions that occurred in the Citeureup Village area, Bandung Regency, especially those related to the $\mathrm{KB}$ Village program which carried out empowerment program interventions with 8 indicators of family functions, including religious functions, social-culture functions, function of love and affection, function of protection, function of reproduction, function of socialization and education, function of economy and function of the environment. Community empowerment can be implemented from various programs, one of them is the optimization of cadres in facilitating community learning needs [12]

Andrew E. Sikula [13] explains that training is a short-term educational process utilizing a systematic and organized procedure by which non-managerial personnel learn technical knowledge and skills for a definite purpose. Development, in reference to staffing and personal matter, is a long term education process utilizing a systematic and organized procedure by which managerial personnel learn conceptual and theoretical knowledge for general purpose.

The training strategies carried out by the instructor to achieve the training objectives are very varied, this is supported 
by the principles of training, namely 1) participation, 2) repetition, 3) relevance, 4) transference and 5) feedback. Seeing these 5 principles, it means that training is inseparable from the daily life of the trainees and also the training participants' environment, so that the training material is functional (useful) for the individual trainees themselves.

The training model with a good approach developed by the instructor is an approach that is able to form active learning citizens to be more courageous and independent and train trainees in communication $[14,15]$. This is proven by the ability training participants to express their opinions, participate actively, have high motivation for training participants, and be active in assignments both individually and in groups [12].

As stated by Abudlhak [16] as follows "In learning activities, learning methods can be interpreted by regular and systematic procedures to teach adults to achieve predetermined learning goals".

The training model with the approach applied in the training group is an effort to establish facilities in the learning process and benefits for training participants.

The other opinions according to Kusnadi [17] are as follows:

" ........ all strategies and learning methods are basically good and can be used by tutors in the learning process, but what needs to be understood is that none of the learning strategies and methods are the best / effective, precise and appropriate, all of them have advantages and disadvantages in their application".

So far, learning in training is increasingly necessary to get closer to learner centered learning, especially to explore the needs of training participants, the learning process in training must equip training participants with something that is needed in the future, throughout life.

The steps for implementing problem-based learning consist of five main stages, starting with the trainer orientating the training participants to authentic problem situations and ending with the presentation of the work. If the range of the problem is moderate, the five stages can be completed in two to three meetings. However, complex problems may take longer to solve.
TABLE I. PROBLEM BASED LEARNING SyNTAX

\begin{tabular}{|l|l|}
\hline \multicolumn{1}{|c|}{ Stage } & \multicolumn{1}{c|}{ Role of Trainer } \\
\hline Prage-1 orientation & $\begin{array}{l}\text { Trainer explains learning objectives, } \\
\text { Explain the required logistics, propose } \\
\text { phenomena or demonstrations or stories } \\
\text { to raise problems, motivate trainees to } \\
\text { engage in solving the problems they } \\
\text { choose }\end{array}$ \\
\hline $\begin{array}{l}\text { Stage-2 } \begin{array}{l}\text { Organizing trainees to Learn } \\
\text { Organize learning tasks related to these } \\
\text { problems }\end{array} \\
\text { Guiding individual and } \\
\text { group investigations }\end{array}$ & $\begin{array}{l}\text { Trainers encourage trainees to collect } \\
\text { appropriate information, carry out } \\
\text { experiments, to get explanations and } \\
\text { problem solving }\end{array}$ \\
\hline $\begin{array}{l}\text { Stage-4 and present the } \\
\text { Develop and } \\
\text { work }\end{array}$ & $\begin{array}{l}\text { Trainers help trainees plan and prepare } \\
\text { appropriate work such as reports, videos } \\
\text { and models and help them to share } \\
\text { assignments with friends }\end{array}$ \\
\hline $\begin{array}{l}\text { Stage-5 analyze and evaluate the } \\
\text { problem-solving process }\end{array}$ & $\begin{array}{l}\text { Trainers help trainees to reflect or } \\
\text { evaluate their investigations and the } \\
\text { processes they use }\end{array}$ \\
\hline
\end{tabular}

From table 1, it can be explained that problem-based learning in the context of setting priority needs is learning that begins with problems that can be raised by both trainees and trainers, then participants deepen their knowledge of what they already know and what they need to know to solve the problem.

Of course, the problems raised are the problems felt by the participants so that the problem can attract attention to be solved so that they are encouraged to play an active role in learning. This problem is solved through group work whose members have been organized, so that participants get various and real learning experiences in the form of collaborative experiences, group interactions and other experiences that are valuable for solving real problems in life.

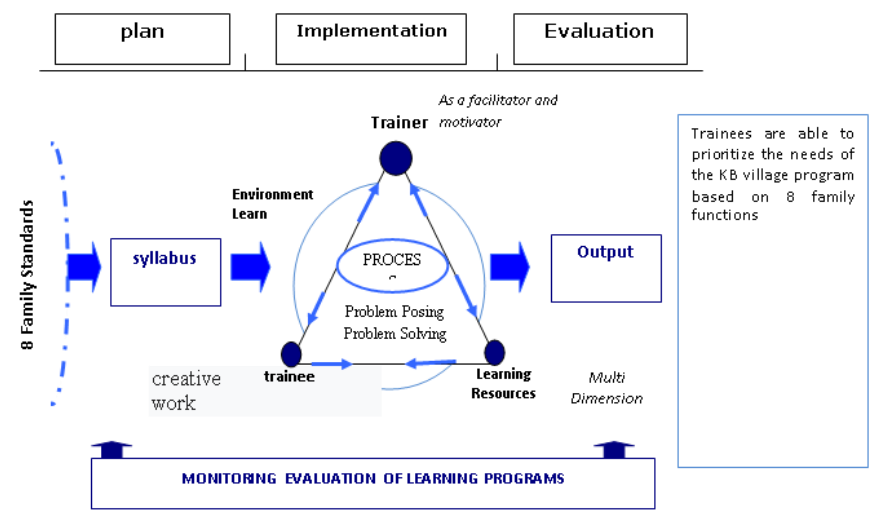

Fig. 1. PBL model in the training program

To explore the learning needs of the community more deeply, a training model is needed with an appropriate approach in accordance with training principles, a learner centered training approach, and a participatory, PBL (Problem Based Learning) approach. PBL according to Amir, Tan and 
Wee [18-20] has characteristics such as: learning begins with giving "problems", usually "problems" have a context with the real world, learners are active in groups to formulate problems and identify knowledge gaps training participants, study and find their own material related to "problems", and report solutions to "problems". Meanwhile, the instructor facilitates more than provides lecture material, namely designing a problem scenario, providing clues indications of additional reading sources and various directions and suggestions needed when the learner runs the process. Although it is not a completely new approach, the application of the PBL method has made rapid progress, especially in a democratic society and grassroots society.

The training model with the PBL approach is one form of model developed from Piaget's and Vygotsky's constructivist learning theory. The basis for this theory is the assumption that knowledge is the result of human construction. Humans construct their knowledge through their interactions with objects, phenomena, experiences, and their environment [21].

The formation and development of the training participants' knowledge takes place through social interaction. Learning for training participants in the PBL model is an effort to achieve knowledge. Knowledge is an understanding, both spontaneous and scientific understanding. Spontaneous understanding is the understanding obtained from the experience of everyday learning citizens and its nature is not defined and structured in a logical systematic way. Meanwhile, scientific understanding is the meaning obtained from formal learning which is logically defined in a broader system.

\section{CONCLUSION}

The application of the training model with a problembased learning approach in setting priorities for the learning needs of the family planning village community in Citeureup Village, Bandung Regency, generally begins with a problem that must be solved. To explore the learning needs of the community more deeply, a training model is needed with an appropriate approach in accordance with the principles of training, a learner centered learning approach, and participatory learning methods, namely PBL (Problem Based Learning). In the application of the training model with a problem-based learning approach, the instructor facilitates more than providing lecture material, namely designing a problem scenario, providing clues-indications of additional reading sources and various directions and suggestions needed when the training participants carry out the process.

The implementation of the PBL model in the training program will make it easier for participants to formulate problems and determine solution steps. Through PBL, the trainees were given ease in developing the framework of needs, solutions to be done, targets that must be achieved and the person in charge of the program.

\section{ACKNOWLEDGMENT}

Thanks to the Institute for Research and Community Service (Lembaga Penelitian dan Pengabdian Kepada Masyarakat, LPPM) Indonesia University of Education for funding this research.

\section{REFERENCES}

[1] Green Paper on Adult Education: Adult Education in an Era of Lifelong Learning. Dublin: Stationery Office. 1998

[2] W.P. Learning, Learning Of Life. Dublin. 2000.

[3] B.D. Christens, "Toward relational empowerment". American Journal of Community Psychology, 50(1-2), 114-128. 2012.

[4] B. Forenza, D.T. Lardier Jr, R.J. Reid, P. Garcia-Reid, and A. Bermea "Exploring community stress and empowerment among stakeholders and youth in an urban community". Journal of Human Behavior in the Social Environment, 29(6), 705-721. 2019.

[5] K.E. Pigg, "Three faces of empowerment: Expanding the theory of empowerment in community development". Community Development, 33(1), 107-123. 2002

[6] R. Amdam, "Empowerment planning in regional development". European Planning Studies, 18(11), 1805-1819. 2010.

[7] A.H.Y. Hon and R.B. Rensvold, "An interactional perspective on perceived empowerment: The role of personal needs and task context". The International Journal of Human Resource Management, 17(5), 959982. 2006.

[8] L. Leach, G. Neutze, and N. Zepke, "Assessment and empowerment Some critical questions". Assessment \& Evaluation in Higher Education, 26(4), 293-305. 2001

[9] S.D. Brookfield, Understanding and Facilitating Adult Learning Buckingham: Open University Press. Buckingham: Open University Press.1996.

[10] M. Aina, Pembelajaran Berbasis Masalah (Problem Based Learning. 2011.

[11] L.J. Moleong, Metodologi Penelitian Kualitatif. Bandung: PT Remaja Rosdakarya. 2006

[12] A. Hufad and S.P. Ardiwinata, Life-Skill Literacy Education Towards Rural Industrial Development. 88(Nfe 2016), 14-16. 2017.

[13] D. Sudjana, Sistem dan Manajemen Pelatihan. Bandung: Falah Production. 2007.

[14] D. Carnine, E. Kameenui, and Maggs, "Components of analytic assistance: Statement saying, concept training, and strategy training". The Journal of Educational Research, 75(6), 374-377. 1982.

[15] A. Hufad and J.S.P. Ardiwinata, "Mentoring Of Women's Empowerment Program". 11(4), 873-879. 2016.

[16] I. Abudlhak, Metoda Pembelajaran Pendidikan Orang Dewasa. Bandung: UPI Press. 2000.

[17] Kusnadi. Metode Pembelajaran Kolaboratif. Tasikmalaya: Edu Publisher. 2015

[18] M. Amir, M. Inovasi Pendidikan Melalui Problem Based Learning. Jakarta: Kencana Prenada Media Group. 2009

[19] O.S. Tan, Problem Based Learning Innovation: Using Problem to Power Learning in 21st Century, thompson Learning. 2003

[20] M.A.K. Wee Kang, Authentic Problem Based Learning: Rewritting Business Education. Prentice Hall. 2002.

[21] P. Vygotsky, Teori Belajar Konstruktivis Piaget dan Vygotsky. Indonesian Digital Journal of Mathematics and Education, 2(3), 191198. 2015. 